\title{
Social responsibility in infrastructure mega-projects: A case study of ecological compensation for Sousa chinensis during the construction of the Hong Kong-Zhuhai-Macao Bridge
}

C The Author(s) 2018. Published by Higher Education Press. This is an open access article under the CC BY license (http:// creativecommons.org/licenses/by/4.0)

\begin{abstract}
Ecological compensation plays an important role in implementing the social responsibility of infrastructure mega-projects. Based on the results of a field study, an in-depth interview, and archive data, this paper introduces the ecological compensation for Sousa chinensis (the Indo-Pacific humpbacked dolphin) during the construction of the Hong Kong-Zhuhai-Macao Bridge. It studies the concrete measures, decision-making processes, and organizational collaboration of the ecological compensation, using the method of a case study. The present study not only enriches our understanding of the ecological compensation practice during the construction of infrastructure mega-projects, but also extends the literature on the social responsibility of infrastructure mega-projects. This sheds light on the protection of the environment as well as biodiversity in the construction of future infrastructure mega-projects.
\end{abstract}

Keywords infrastructure mega-projects, social responsibility, ecological compensation, Hong Kong-Zhuhai-Macao Bridge, Sousa chinensis

Received November 5, 2017; accepted November 29, 2017

Zheming LIU, Liangyan WANG ( $($ )

Antai College of Economics and Management, Shanghai Jiao Tong University, Shanghai 200240, China

E-mail: wly@sjtu.edu.cn

Zhaohan SHENG

School of Management and Engineering, Nanjing University, Nanjing 210093, China

Xinglin GAO

Hong Kong-Zhuhai-Macao Bridge Authority, Zhuhai 519060, China

This work was funded by National Natural Science Foundation of China: 71390525, National Natural Science Foundation of China: 71620107004 and Shanghai Excellent Academic Leaders Program: 14XD1402200

\section{Introduction}

Infrastructure mega-projects, which are large-scale engineering facilities providing fundamental public services for social production, economic growth, and people's everyday lives, are playing an increasingly crucial role in world development (Brookes, 2014; Flyvbjerg, 2011). They can bring a series of profound impacts to society, including economic development (Banerjee et al., 2012; Gibson and Olivia, 2010), poverty reduction (Ferraro and Hanauer, 2014), productivity promotion (Aschauer, 1989; Demetriades and Mamuneas, 2000; Haughwout, 2002), social resource redistribution (Behrens, 2011), and urban-rural coordination (Shen et al., 2012). There are several characteristics of infrastructure mega-projects: They involve huge investments, long implementation cycles, high levels of complexity, various stakeholders, and potential environmental risks (O'Connor et al., 2015; Qiu, 2007; Zeng et al., 2015), which makes it a great challenge to build and manage infrastructure mega-projects (Ma et al., 2017). Therefore, due to the crucial strategic role and complexity of infrastructure mega-projects, issues about the social responsibility and sustainability of infrastructure mega-projects have attracted widespread attention from scholars and experts both in academia and the industry (Flyvbjerg, 2014; Lin et al., 2016; Miller and Hobbs, 2005).

The past decades have witnessed a great boom of infrastructure investment in China. A large number of world-famous infrastructure mega-projects, such as the Three-Gorges Dam, the Qinghai-Tibet Railway, and the West-to-East Natural Gas Transmission Project, have been successfully built and operated in China (He et al., 2015; Peng et al., 2007; Qiu, 2007; Zeng et al., 2015). Since the Belt and Road Initiative was put forward by Chinese Government in 2013 and the Belt and Road Forum for 
International Cooperation was successfully held in Hangzhou in 2017, it can be expected that there will be more and more investments in infrastructure mega-projects both in China and in the rest of the world.

However, although China has made great achievements in regard to the construction and management of infrastructure mega-projects, it is indispensable to realize the intense conflicts that exist between infrastructure megaproject construction and ecological protection. China's environmental condition is already one of the worst among all of the major countries in the world (Liu and Diamond, 2005) and, ironically, the infrastructure mega-project boom is likely to make these environmental problems in China, especially in regard to biodiversity protection, even more severe. For example, the construction of the Three-Gorges Dam caused a great number of fragmented habitat islands, which has significantly affected the biodiversity and ecosystem properties of the region of the Three-Gorges Reservoir Area and has threatened the lives of aquatic animals in the Yangtze River (Stone, 2008; Xie, 2003; Wu et al., 2003). Moreover, the rapid spread of China's highspeed railway network consumes stunning quantities of cement and steel (Lin et al., 2017a). The high energy intensity of raw material production engenders substantial emissions of greenhouse gases during the construction and maintaining phases of the high-speed railway network, which is speeding up the process of global warming (Westin and Kågeson, 2012), resulting in a sharp decline in the populations of many species.

How can the deterioration of the environment and the degradation of biodiversity caused by the construction of infrastructure mega-projects be avoided? This question needs to be addressed. Because it is almost impossible to prevent the environment from being affected during the construction of infrastructure mega-projects, ecological compensation, an important part of social responsibility of infrastructure mega-projects, is a good way to alleviate the damage of infrastructure mega-project construction to the environment. However, although there are many existing studies about the impact of infrastructure mega-projects on the environment, as well as the measures taken to avoid or alleviate this influence (Peng et al., 2007; Tam et al., 2004), there has been insufficient research conducted about ecological compensation, especially during the construction period of infrastructure mega-projects. Taking the ecological compensation for Sousa chinensis (the IndoPacific humpbacked dolphin) during the construction of the Hong Kong-Zhuhai-Macao Bridge (HZMB) as a typical case, this paper studies the concrete measures and analyzes the decision-making processes and organizational collaboration of the ecological compensation carried out, based on the results of a field study, an in-depth interview, and archive data.

The present study contributes to the existing literature in various aspects. First, there has been insufficient research about ecological compensation, especially the practices in
China, this paper conducts a comprehensive case study and fills this research gap; this enriches our understanding of the ecological compensation practice during the construction of infrastructure mega-projects effectively. Second, because ecological compensation is an important part of social responsibility of infrastructure mega-projects, this paper extends the contents of infrastructure mega-projects social responsibility and contributes to the development of the theory of infrastructure mega-projects social responsibility. Third, the conflicts between infrastructure megaprojects construction and environmental protection become a serious problem in the developing countries, this paper provides a successful example which can be learned and followed by infrastructure mega-projects constructed in other developing countries, which sheds light on the protection of the environment and biodiversity in the construction of future infrastructure mega-projects worldwide.

We organize the remainder of this paper in the following way. In Section 2, we briefly review recent research in related fields, including the social responsibility of infrastructure mega-projects, as well as ecological compensation. Then, we present the research design of our study in Section 3. This is followed by a case study of ecological compensation for Sousa chinensis during the construction of the HZMB, in which the specific measures, decision-making processes, and organizational collaboration of the ecological compensation carried out are introduced. Finally, in Section 5, we set out our conclusions and end with a discussion of the limitations of our study, along with suggestions for future research.

\section{Literature review}

\subsection{The social responsibility of infrastructure mega-projects}

Introduced in the 1950s (Bowen, 1953), corporate social responsibility (CSR) has received a proliferation of attention and has become a research hotspot in academia since the 1990s (Aguilera et al., 2007; Campbell, 2007; Carroll, 1999). After being developed for more than 20 years, a number of research studies focusing on various topics, including conceptual models of CSR (Carroll, 1991; Garriga and Melé, 2004; Shaw and Post, 1993) and the financial effects of CSR (Brammer and Millington, 2008; Godfrey, 2005; Wang and Qian, 2011), as well as other spillovers of CSR (Ciliberti et al., 2008; Jones et al., 2014; Tseng et al., 2009), have contributed to a systematic theoretical framework and abundant empirical evidence in the field of CSR.

However, research related to the social responsibility of engineering projects is relatively insufficient and scattered (Lin et al., 2017c; Ma et al., 2017). Most of these studies merely focus on the social responsibility of companies in the construction industry or on the social responsibility of 
projects in a specific phase, rather than considering the issues at the project-level from the perspective of a whole lifecycle (Zeng et al., 2015). For example, Zeng et al. (2003) researched the antecedents of contractors' environmental performance. Qi et al. (2010) focused on the drivers for contractors' green innovation, based on evidence from the construction industry. Zhao et al. (2012) established a series of indicators to assess the social responsibility of firms worldwide in the construction industry. In the mid2010 s, a study on the social responsibility of megaprojects has developed this field. Zeng et al. (2015) put forward the concept of megaproject social responsibility (MSR) and defined it as "the policies and practices of the stakeholders participated through the whole project lifecycle that reflects responsibilities for the well-being of the wider society." They further constructed the framework of MSR into three dimensions: project lifecycle dynamics, stakeholders' heterogeneity, and social responsibility interactivity. A conceptual governance framework of MSR and an indicator system for evaluating MSR were then established (Lin et al., 2017b; Ma et al., 2017) and the topic of MSR has attracted more and more attention from scholars and the public since.

\subsection{Ecological compensation in infrastructure mega-projects}

Ecological compensation is the substitution of ecological functions or qualities that are impaired by development (Cuperus et al., 1996, 1999); it plays one of the most indispensable roles in the social responsibility of infrastructure mega-projects. In general, the main purpose of ecological compensation is either to improve damaged areas or to create new habitats with ecological functions and quality attributes (Allen and Feddema, 1996). For specific engineering projects, ecological compensation refers to the mitigation measures used to minimize environmental impacts during a project's construction and operation, to restore the site and to compensate for residual impacts (NOAA, 1997). After decades of development, ecological compensation has already been established as an effective measure that is always adopted in the development of infrastructure mega-projects, in order to balance efficiency and equity and protect the environment from being destroyed (Yu and $\mathrm{Xu}, 2016$ ). In practice, a number of countries have already taken ecological compensation measures to compensate for the environmental impacts of human activities, especially engineering projects, on the habitats of plants and animals (Trussart et al., 2002; Xu et al., 2015).

As an important means of environmental protection, the issues of ecological compensation for engineering projects have been a concern worldwide and research in this field is quite fruitful. Cuperus et al. (1996, 1999, 2001, and 2002) carried out a series of studies on the ecological compensa- tion involved in the improvement of the Dutch highway network, including the guidelines for the ecological compensation and the specific ecological compensation measures in the planning phase, as well as the preparation and implementation of the ecological compensation measures. Seen through a review of the environmental impact assessment records for this decision, Villarroya and Puig (2013) explored the particular role that ecological compensation has had in road and railway environmental impact assessment procedures in Spain.

In the context of China, the ecological compensation of infrastructure mega-projects in China is still an emerging research field. The measures taken for ecological compensation during the construction of the Qinghai-Tibet Railway attracted wide attention of scholars and practitioners. To avoid affecting the migratory route of wildlife, 33 passageways were designed to enable wildlife on the plateau to go under the arches to get from one side of the railway to the other (Qiu, 2007). And grassland vegetation and its root soil layer were removed during the construction of the railway and they were replanted as soon as the work was complete (Peng et al., 2007). In addition, focusing on the ecological compensation carried out for hydropower projects, Yu and $\mathrm{Xu}$ (2016) and Yu et al. (2016a, 2016b) constructed a complete ecological compensation mechanism framework to avoid partial compensation for large hydropower projects. They also proposed a cascade ecological compensation development mode for hydropower development in China.

However, there are still a large number of problems regarding the theory and practice of ecological compensation for engineering projects. As pointed out by Fang and Elliott (2016), the policy of ecological compensation is frequently misused in China. Project developers tend to choose to pay government authorities directly rather than restore ecosystems; in this way, the measures of ecological compensation are essentially reduced to buying the right to damage the environment. Ecosystem thereby cannot be protected. Moreover, due to the complexity of infrastructure mega-projects (Baccarini, 1996; Bosch-Rekveldt et al., 2011; Vidal et al., 2011), ecological compensation for infrastructure mega-projects ought to be totally different from that for general engineering projects. Therefore, more research on the issue of ecological compensation for infrastructure mega-projects is needed.

\section{Research design}

A case study is an empirical inquiry, the focus of which is on a contemporary phenomenon within its real-life context. Case studies are suitable for studying complex social phenomena (Yin, 2013). The resulting body of case study research has had a prominent place in many disciplines and professions for a long time, ranging from 
psychology, anthropology, sociology, and political science to education, clinical science, social work, and administrative science (Mills et al., 2010). Case studies have also been widely adopted as a qualitative research method in the literature of humanities and social science disciplines in the past few decades (Eisenhardt, 1989; Geels, 2002; Pauget and Wald, 2013). The design of a case study can be categorized into single- or multiple-case studies. In this paper, we conduct a single-site case study, which allows for an in-depth qualitative investigation of the ecological compensation process (Ben-Menahem et al., 2016).

Our study focuses on the ecological compensation for Sousa chinensis during the construction of the HZMB. Following the Three-Gorges Dam, the QinghaiTibet Railway, the South-to-North Water Diversion Project, and the West-to-East Natural Gas Transmission Project, the HZMB is another world-famous Chinese infrastructure mega-project which will have a great impact on the economy, society, and environment in China and the rest of the world. Moreover, the route of the HZMB determined by the experts inevitably crosses the largest Sousa chinensis reserve in China, Guangdong Pearl River Estuary Sousa chinensis National Nature Reserve; this is a huge threat to the rare marine mammal, Sousa chinensis. How to prevent Sousa chinensis from being hurt during the construction of the HZMB? This is a question concerned by the scholars, experts, and practitioners all over the world. The case of the ecological compensation for Sousa chinensis during the construction of the HZMB gives a successful and typical example of reconciling the conflicts between the construction of infrastructure mega-projects and the protection of rare species, and the experiences of the HZMB shed light on the environmental protection of future infrastructure megaprojects.

To gain a comprehensive understanding of the measures and processes of the ecological compensation involved in the HZMB project, we visited the HZMB twice between 2015 and 2017, and undertook a sequence of in-depth field studies at the steel bridges, immersed tunnels, and artificial islands of the HZMB, as well as in the Pearl River Estuary Sousa chinensis National Nature Reserve. Moreover, we conducted a semi-structured interview with the chief engineer of the HZMB Authority about the decisionmaking processes and organizational collaboration involved in the ecological compensation for Sousa chinensis. We also based our case study on archive data, including research reports entitled "Intermediate Achievement on the Feasibility Study of HZMB," written by the Planning and Research Institute of the Ministry of Transport, and "The Thematic Research Report about the Influence of HZMB Project on Sousa chinensis in the Pearl River Estuary," written by the South China Sea Fisheries Research Institute, the Chinese Academy of Fishery Sciences.

\section{Case study}

\subsection{Background}

Connecting Hong Kong, Zhuhai, and Macao, the HZMB is a large cross-sea passage with bridges, tunnels, and artificial islands. It is approximately $56 \mathrm{~km}$ in length, with an expected service life of 120 years and total investment estimated at about 105 billion CNY; this makes the HZMB the longest cross-sea bridge and the cross-sea bridge with the largest investment in the world. As a remarkable infrastructure mega-project, the HZMB has had a great deal of influence on economic and social development in the China's mainland, Hong Kong, and Macao. In early April 2005, the Transportation Department of Chinese National Development and Reform Commission held a technology scheme demonstration meeting for the location of the HZMB. After a comprehensive demonstration and comparison, the expert group recommended a route from San Shek Wan to Zhuhai Gongbei/ Macao Pearl. The route started from San Shek Wan on Lantau Island, which is in the neighborhood of the new Hong Kong airport, then continued west across the Guangdong/Hong Kong border, and finally reached the Zhuhai Gongbei Port and Macao. This route was able to meet all the requirements of the three governments (Guangdong, Hong Kong, and Macao) and maximize the economic and social benefits of the three regions. However, this route inevitably crosses the largest Sousa chinensis reserve in China, namely, the Guangdong Pearl River Estuary Sousa chinensis National Nature Reserve, including its core area, which spans about $9 \mathrm{~km}$, and its buffer zone, spanning about $5.5 \mathrm{~km}$. The affected oceanic area occupies up to $29 \mathrm{~km}^{2}$.

Sousa chinensis, also known as the Indo-Pacific humpbacked dolphin, is one of 78 species of cetaceans in the world and is currently the only existing national firstgrade attentive protected cetacean in China. Because of its rarity, Sousa chinensis was listed in the Chinese Red List of Endangered Animal Species in 1988, is regarded as near extinction by the International Union for Conservation of Nature (IUCN) Red List, and is known colloquially as a "mermaid" or "aquatic panda." Sousa chinensis inhabits estuaries, a mixing zone of fresh and salt water in subtropical sea areas. It is now found mainly in places such as the Western Pacific Ocean and the Indian Ocean. In China, Sousa chinensis is mainly distributed along the south-east coast, from the Yangtze River estuary in the north, extending southward to the Zhejiang, Fujian, Taiwan, Guangdong, and Guangxi coastal estuaries, including Guangdong Pearl River Estuary, one of the most important habitats of Sousa chinensis in the world.

Nevertheless, as a result of marine pollution, habitat shrinkage, and low reproductive rates (Sousa chinensis only has one child every three years), Sousa chinensis is 
heading for decline and is even at risk of extinction. In 2010, before the construction of the HZMB began, the total number of Sousa chinensis distributed in Lingding Bay waters in Zhuhai (excluding Hong Kong waters) was only about 1200 , less than the population of the panda, as monitored by the South China Sea Fisheries Research Institute, the Chinese Academy of Fishery Sciences. The survival of Sousa chinensis faces challenges and the HZMB's traversing of this nature reserve will undoubtedly bring about a severe negative impact on the living conditions of Sousa chinensis.

One potential risk during the construction of the HZMB concerns the underwater blasting operation, which is likely to directly kill or injure Sousa chinensis. With the large range of the underwater blasting operation, it is difficult to take effective measures to ensure that no Sousa chinensis is in the affected area and to avoid them being killed or injured. For example, when the new Zhuhai airport was built in December 1993, the blasting of Fortress Hill on land led to the deaths of a number of Sousa chinensis in the nearby waters. Likewise, from 1993 to 1995, the construction of the new international airport at Chek Lap Kok in Hong Kong also killed Sousa chinensis during the engineering blasting on islands and coasts. In consideration of their scarcity, the casualties of Sousa chinensis may directly affect the survival of the entire species. In addition to this, there are other harmful ecological effects of underwater blasting, such as killing other aquatic organisms and producing suspended solids.

The suspended solids and pollutants produced during construction will pollute the sea water, the place in which Sousa chinensis live. Bridge and immersed tunnel construction requires large-scale seabed excavation and backfilling, which increases the suspended solids in the water, forms a turbid area, results in the decline of water transparency and oxygen content, and will finally affect the water quality in the Sousa chinensis reserve. Instead of direct effects, the suspended solids will increase the risk of surface bacterial infection in Sousa chinensis and even cause skin diseases for injured and weak dolphins. In addition to this, although the fish in the Sousa chinensis reserve have a high level of adaptability to turbid water, the consumption of dissolved oxygen by suspended organic matter may lead to the decrease of oxygen content in the water and an avoidance reaction in the fish, which will indirectly affect the foraging behavior of Sousa chinensis.

Meanwhile, the piers and artificial islands of the HZMB may permanently change the characteristics of nearby currents, causing variations in the flow field. The change in the flow field will influence the local benthic ecosystem through hydrological and geographical factors, resulting in the mutative quantity and distribution of demersal fishes. This will in turn affect the food sources of Sousa chinensis. Moreover, the continuous noise occurring during the construction of the HZMB, including the noise from traffic and offshore construction, can disturb the echoloca- tion system of Sousa chinensis, weaken their capacity to forage, communicate, and respond, and thus threaten their everyday lives.

In conclusion, the construction and operation of the HZMB project may have negative impacts on the habitat, vivosphere, and individual organisms of Sousa chinensis from a variety of aspects, causing irreparable damage in both direct and indirect ways. This results in a serious contradiction between the infrastructure mega-project construction and eco-environmental protection, and it is necessary to urgently take action to protect Sousa chinensis.

\subsection{Ecological compensation for Sousa chinensis}

To mitigate the negative impact of the construction of the HZMB on Sousa chinensis, the developers of the HZMB have taken a series of targeted measures, including optimizing the design scheme, improving construction methods, strengthening construction management, and adopting ecological compensation. This paper focuses on the ecological compensation measures undertaken during the construction of the HZMB.

Ecological compensation is an institutional arrangement, adjusting the interest relations between different stakeholders by economic means for the purpose of the protection and sustainability of ecosystem services. More specifically, the ecological compensation mechanism is a public institution that uses a mix of administrative and market-oriented levers to adjust the relationships between different interests, according to ecosystem service values, ecological protection costs, and developmental opportunity costs, with the intention of protecting the environment and promoting harmonious development between humans and nature. The HZMB will inevitably cross the Guangdong Pearl River Estuary Sousa chinensis National Nature Reserve; nevertheless, the extant literature regarding Sousa chinensis ecological surveys in the Pearl River estuary are insufficient. With limited scientific basis, the impact analysis and prediction conclusions are inaccurate. Therefore, in order to ensure the survival and development of Sousa chinensis, it is indispensable to strengthen scientific research, implement safeguards, and provide protection. The HZMB project has the responsibility and obligation to take the necessary ecological compensation measures.

About a year after the official approval of the Sousa chinensis protection decision, the South China Sea Fisheries Research Institute proposed a series of suggestions for the ecological compensation that should be undertaken, which acted as references for the engineering unit and the administrative department. After a year of demonstration, tests, and improvements by the Administration of Ocean and Fisheries of Guangdong Province, the Administration of Fishery and Fishing Harbor Supervision of the PRC, and the HZMB Previous Work Coordination 
Group, on December 4, 2007, the Administration of Ocean and Fisheries of Guangdong Province proposed a preliminary ecological compensation plan, including the construction of Sousa chinensis rescue and nursery bases, ecological protection research on Sousa chinensis, supervision expenses for the construction period, Sousa chinensis monitoring expenses during the construction and operation periods, food organisms enhancement in the reserve, and economic compensation for the Sousa chinensis supervision station on the offshore artificial island. The total budget amounted to approximately CNY 150 million.

After the preliminary eco-compensation scheme was put forward, the HZMB Previous Work Coordination Group immediately convened a meeting involving the governments of Guangdong, Hong Kong, and Macao to discuss the feasibility of a framework agreement with the Administration of Ocean and Fisheries of Guangdong Province, on the basis of the preliminary eco-compensation scheme provided by the Administration of Ocean and Fisheries of Guangdong Province and Sousa chinensis National Nature Reserve Bureau. For more details and to ensure traceability, the governments of Guangdong, Hong Kong, and Macao requested that the Administration of Ocean and Fisheries of Guangdong Province provide adequate basis materials, mainly including a list of the national or provincial regulations and policies for each project, contents, and budgets, and the calculation of compensation criteria. As for the projects without available basis or cost calculation criteria, it is necessary for the reasons or reference projects to be exactly explained and fully justified. On March 28, 2008, the Administration of Ocean and Fisheries of Guangdong Province provided specific materials for the eco-compensation plan. The governments of Guangdong, Hong Kong, and Macao agreed with the creditability and feasibility of the ecocompensation scheme and, on April 16, 2008, the office sent the materials to the Guangdong Provincial Develop- ment and Reform Commission. Three months later, the leaders of the Guangdong Provincial Development and Reform Commission and Administration of Ocean and Fisheries of Guangdong Province held a conference on the ecological compensation of Sousa chinensis and reached a preliminary consensus.

The preliminary ecological compensation is estimated for the overall plan. However, considering the actual situation, the ecological compensation measures are plan to be taken in two phases. The first phase focuses on the priority safeguarding measures and the second phase measures depend on further evaluation, according to the actual ecological impact, within one year after the project is completed. As the construction period of the HZMB is comparatively long, it is necessary to further explore the details of ecological compensation measures during the operation period. At present, only the ecological compensation issues in the construction period have been taken into consideration. This means that the ecological compensation scheme is studied at different stages, instead of as a whole. Adjusting the specific expenses in accordance with the ecological investigation results, the Administration of Ocean and Fisheries of Guangdong Province submitted the compensation agreement on July 21, 2008. The ecological compensation problem was solved in two periods, the cost of the first phase of compensation reaching CNY 80 million. The specific plans are shown in Table 1.

The HZMB Previous Work Coordination Group then forwarded the ecological compensation scheme to the governments of Guangdong, Hong Kong, and Macao, and then finalized the scheme, based on feedback from them. On November 10, 2008, the Research Report of the Impact of HZMB on Pearl River Estuary Sousa chinensis was authorized by the Administration of Fishery and Fishing Harbor Supervision, Ministry of Agriculture. This event represents the way in which the Sousa chinensis protection decision scheme for the HZMB has taken shape, which

Table 1 The first-phase compensation scheme

\begin{tabular}{|c|c|c|c|}
\hline No. & Project & Content & $\begin{array}{l}\text { Compensation estimation } \\
\text { (thousand CNY) }\end{array}$ \\
\hline$\overline{1}$ & $\begin{array}{l}\text { Construction of Sousa chinensis } \\
\text { rescue and nursery bases }\end{array}$ & $\begin{array}{c}\text { Ensure the: rescue, nursing, research, release, and rehabilitation of } \\
\text { Sousa chinensis }\end{array}$ & 55000 \\
\hline 2 & $\begin{array}{l}\text { Ecological protection research on } \\
\text { Sousa chinensis }\end{array}$ & $\begin{array}{l}\text { Includes research on ecology, acoustics, behavioral science, } \\
\text { reproductive physiology, genetics, disease control, physical } \\
\text { and chemical environment, and ingestion }\end{array}$ & 3600 \\
\hline 3 & $\begin{array}{l}\text { Supervision expenses in the period } \\
\text { of construction (six years) }\end{array}$ & $\begin{array}{l}\text { (1) One on-site supervision vessel; ( } 2.8 \text { million CNY in budget) } \\
\text { (2) Offshore Sousa chinensis rescue; ( } 3 \text { million CNY in budget) } \\
\text { (3) Vessel operating fee; (5.1 million CNY in budget, including } 2.8 \text { million CNY of } \\
\text { fuel and } 2.3 \text { million CNY of maintenance) }\end{array}$ & 10900 \\
\hline 4 & $\begin{array}{l}\text { Sousa chinensis monitoring expenses } \\
\text { during construction }\end{array}$ & 1 million CNY in budget each year, for a total of six years & 6000 \\
\hline \multirow[t]{2}{*}{5} & $\begin{array}{l}\text { Food organism enhancement } \\
\text { in the reserve }\end{array}$ & $\begin{array}{l}\text { Food organism enhancement and release ( } 3 \text { million fish each year; } 0.25 \mathrm{CNY} \text { per } \\
\text { fish for a total of six years) }\end{array}$ & 4500 \\
\hline & Total & & 80000 \\
\hline
\end{tabular}


provides an important foundation for the construction and operation of the HZMB.

The decision-making process of ecological compensation for Sousa chinensis in regard to the HZMB is shown in Fig. 1.

\subsection{Organizational collaboration for ecological} compensation

The ecological compensation scheme was completed successfully in less than a year, which entailed a great deal of successful collaboration and close coordination among the organizations involved.In the process of developing the ecological compensation scheme, the South China Sea Fisheries Research Institute acted as the implementer of basic research and put forward initial proposals; the Administration of Ocean and Fisheries of Guangdong Province was the builder of the scheme structure, revising and perfecting the scheme; the HZMB Previous Work Coordination Group and the Coordination Group Office coordinated the three governments; the Development and Reform Commission of Guangdong Province was entrusted by the Coordination Group to act as the main body of coordination in the decision-making process; and the governments of Guangdong, Hong Kong, and Macao gave advice and made final decisions.

The organizational collaboration processes of the ecological compensation for Sousa chinensis are shown in Fig. 2.

\subsection{Outcomes of ecological compensation}

The close coordination and joint efforts of related organizations led to effective results for Sousa chinensis protection in the construction of the HZMB. Back in 2010, when the construction of the HZMB had not started, the HZMB Authority entrusted the South China Sea Fisheries Research Institute, the Chinese Academy of Fishery Sciences, with background measurements. The measurements were taken through line transect sampling, which is widely accepted internationally and often used in Hong Kong. In this case, it involved sailing along a straight line in a selected area, recording the frequency of seeing Sousa chinensis, building a data model, and estimating the average distribution of Sousa chinensis in the area based on this model. According to the estimated data at that time, there were about 1200 Sousa chinensis distributed throughout the waters of Lingdingyang Bay in Zhuhai (excluding the waters of Hong Kong). By September 2015, after nearly five years of bridge construction, the occurrence frequency of Sousa chinensis in the Pearl River estuary of Guangdong did not decrease, but rather rose by an obvious amount. According to statistics, from April to August 2011, the Sousa chinensis monitoring group voyaged 44 times, across $3337.7 \mathrm{~km}$ and $206.19 \mathrm{~h}$, and witnessed 742 Sousa chinensis; from April to August
2015, the monitoring group voyaged 31 times, across $3247.3 \mathrm{~km}$ and $166.54 \mathrm{~h}$, and witnessed 1012 Sousa chinensis. The monitoring group shortened the voyage after four years, but witnessed more Sousa chinensis. Shortly before the main structure of the HZMB was finished, the Pearl River Estuary Sousa chinensis National Nature Reserve Bureau witnessed 1890 Sousa chinensis in total in 2016, according to the Gazette of the State of Marine Environment of Guangdong Province in 2016, issued by the Oceanic and Fishery Administration of Guangdong Province. From 2010 to 2017, as the HZMB project neared completion, the number of Sousa chinensis did not decrease, but increased by more than $50 \%$ (see Table 2). Moreover, since the start of the main construction, there has never been an accident involving Sousa chinensis caused directly by the construction, nor has there been a major marine pollution accident or the death of Sousa chinensis caused by a pollution accident. At the same time, the protection of Sousa chinensis in the HZMB has also been recognized by the South China Sea Fisheries Research Institute, the Chinese Academy of Fishery Sciences, and the Oceanic and Fishery Bureau of Guangdong Province. The head of the Oceanic and Fishery Bureau of Guangdong Province acknowledged that Sousa chinensis didn't leave due to the construction of the HZMB and that ocean exploitation was combined organically with environmental protection in this case.

It is fully proven by the above evidence that the ecological compensation measures for Sousa chinensis have been effective in the construction of the HZMB. Environmental social responsibility was fulfilled, with effective collaboration and close coordination conducted among the South China Sea Fisheries Research Institute, the Oceanic and Fishery Bureau of Guangdong Province, the HZMB Previous Work Coordination Group and Coordination Group Office, the Development and Reform Commission of Guangdong Province, the governments of Guangdong, Hong Kong, and Macao, and other related organizations. This case also powerfully demonstrates that infrastructure mega-projects are not contradictory to environmental protection; as long as they are properly handled, they can exist together in harmony. This is a typical successful case that solved the problem of species protection in the construction of infrastructure megaprojects; it sets a good example for infrastructure megaprojects actively fulfilling their social responsibility. The successful experience of ecological compensation for Sousa chinensis in the case of the HZMB is of significance for infrastructure mega-projects across China and the rest of the world.

\section{Conclusions and discussion}

Taking the ecological compensation for Sousa chinensis during the construction of the HZMB as a typical case, this 


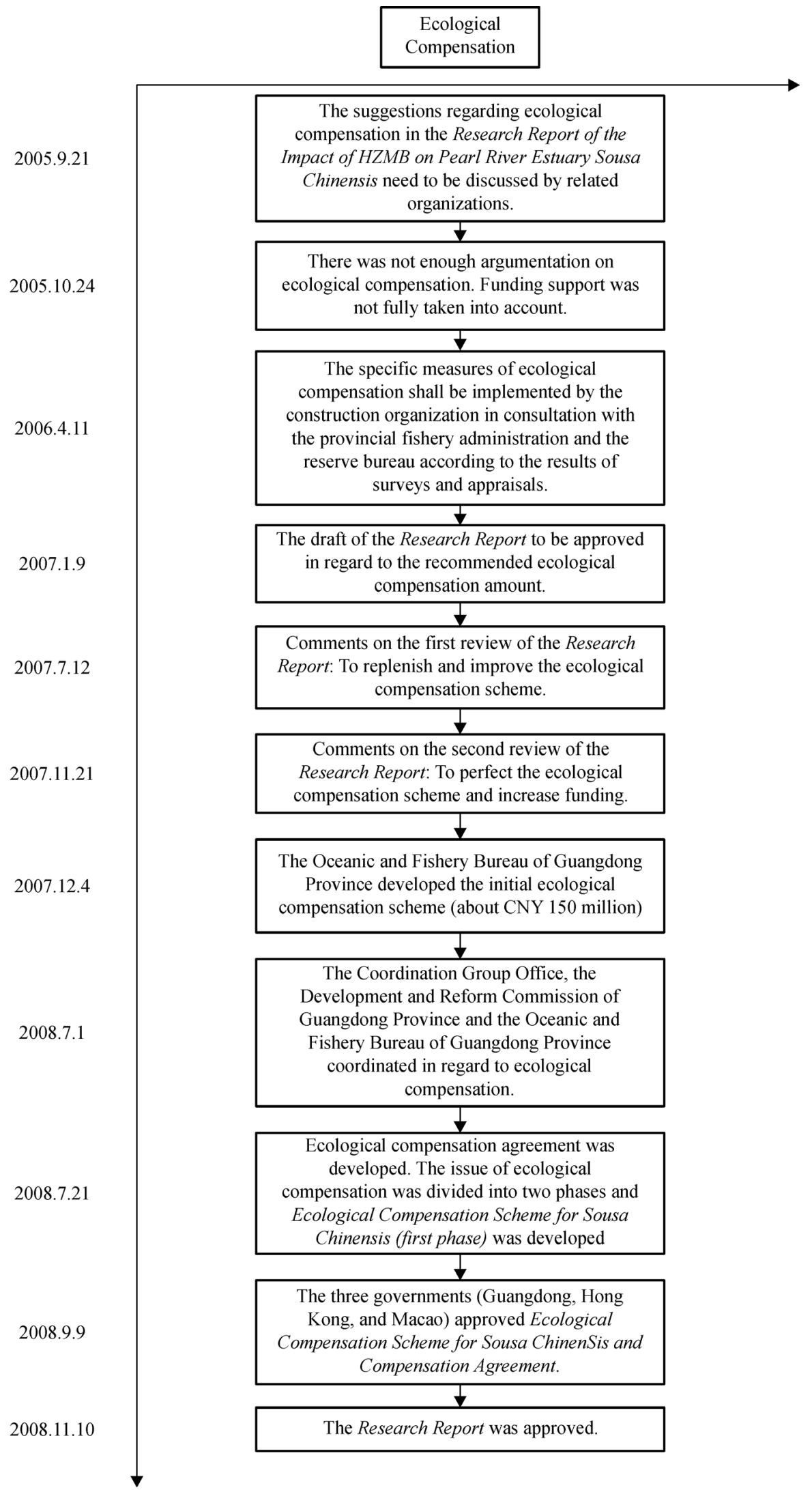

Fig. 1 The decision-making process of ecological compensation for Sousa chinensis in regard to the HZMB 


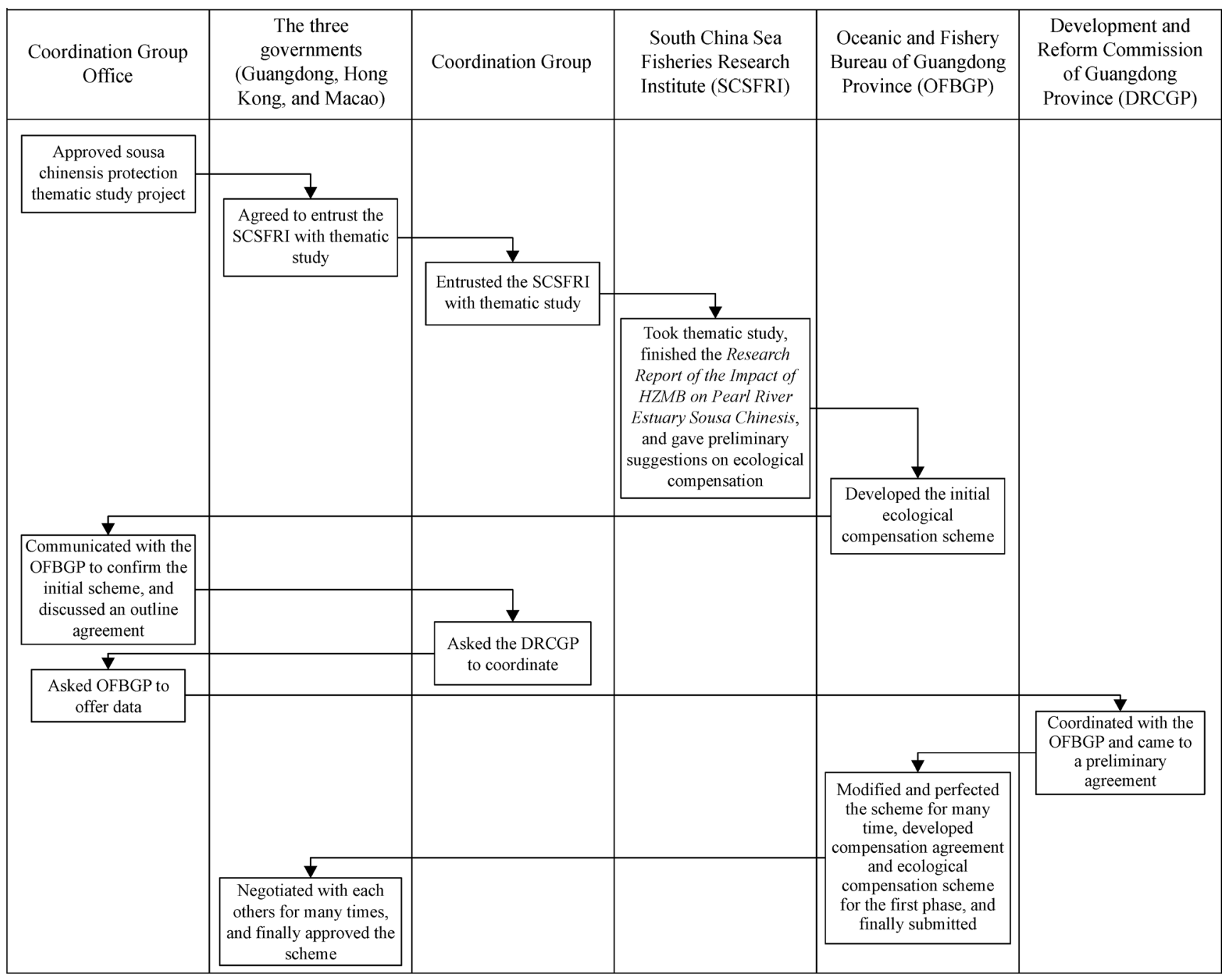

Fig. 2 The organizational collaboration processes for ecological compensation regarding Sousa chinensis in the case of the HZMB

Table 2 The population growth of Sousa chinensis

Panel A: Evidences from overall estimate

\begin{tabular}{lc}
\hline Year & Population number \\
\hline 2010 & 1200 \\
2016 & 1890 \\
Annual growth rate/\% & 7.86 \\
\hline Panel B: Evidences from sample survey & Population number/km \\
\hline Year & 0.222 \\
\hline 2011 & 0.312 \\
Annual growth rate/\% & 8.88 \\
\hline
\end{tabular}

paper studies the concrete measures, decision-making processes, and organizational collaboration in regard to ecological compensation for infrastructure mega-projects.
This study develops the ecological compensation mechanism in regard to infrastructure mega-projects and enriches our understanding of the ecological compensation practice 
during the construction of infrastructure mega-projects. The successful experience of the ecological compensation for Sousa chinensis during the construction of the HZMB can be a good example and reference for future infrastructure mega-projects, especially cross-sea bridges or tunnels, in terms of environmental protection.

Although the ecological compensation for Sousa chinensis has made some preliminary achievements, there is still a long way to go to protect Sousa chinensis throughout the lifecycle of the HZMB. Therefore, the ecological compensation mechanism for Sousa chinensis in the operational phase of the HZMB should be established and studied. Future research should focus on the ecological compensation for Sousa chinensis in the operational phase of the HZMB and contribute to the lifecycle ecological compensation mechanism of infrastructure mega-projects.

\section{References}

Aguilera R V, Rupp D E, Williams C A, Ganapathi J (2007). Putting the $\mathrm{S}$ back in corporate social responsibility: a multilevel theory of social change in organizations. Academy of Management Review, 32(3): 836-863

Allen A O, Feddema J J (1996). Wetland loss and substitution by the Section 404 permit program in southern California, USA. Environmental Management, 20(2): 263-274

Aschauer D A (1989). Is public expenditure productive? Journal of Monetary Economics, 23(2): 177-200

Baccarini D (1996). The concept of project complexity - a review. International Journal of Project Management, 14(4): 201-204

Banerjee A, Duflo E, Qian N (2012). On the road: access to transportation infrastructure and economic growth in China (No. w17897). National Bureau of Economic Research

Behrens K (2011). International integration and regional inequalities: how important is national infrastructure? Manchester School, 79(5): 952-971

Ben-Menahem S M, Von Krogh G, Erden Z, Schneider A (2016). Coordinating knowledge creation in multidisciplinary teams: evidence from early-stage drug discovery. Academy of Management Journal, 59(4): 1308-1338

Bosch-Rekveldt M, Jongkind Y, Mooi H, Bakker H, Verbraeck A (2011). Grasping project complexity in large engineering projects: the TOE (technical, organizational and environmental) framework. International Journal of Project Management, 29(6): 728-739

Bowen H R (1953). Social Responsibilities of the Businessman. New York: Harper \& Brothers

Brammer S, Millington A (2008). Does it pay to be different? An analysis of the relationship between corporate social and financial performance. Strategic Management Journal, 29(12): 1325-1343

Brookes N J (2014). Mankind and mega-projects. Frontiers of Engineering Management, 1(3): 241-245

Campbell J L (2007). Why would corporations behave in socially responsible ways? An institutional theory of corporate social responsibility. Academy of Management Review, 32(3): 946-967
Carroll A B (1991). The pyramid of corporate social responsibility: toward the moral management of organizational stakeholders. Business Horizons, 34(4): 39-48

Carroll A B (1999). Corporate social responsibility: evolution of a definitional construct. Business \& Society, 38(3): 268-295

Ciliberti F, Pontrandolfo P, Scozzi B (2008). Investigating corporate social responsibility in supply chains: s SME perspective. Journal of Cleaner Production, 16(15): 1579-1588

Cuperus R, Bakermans M M G J, Haes H A U D, Canters K J (2001). Ecological compensation in Dutch highway planning. Environmental Management, 27(1): 75-89

Cuperus R, Canters K J, Udo de Haes H A, Friedman D S (1999). Guidelines for ecological compensation associated with highways. Biological Conservation, 90(1): 41-51

Cuperus R, Canters K J, Piepers A A (1996). Ecological compensation of the impacts of a road: preliminary method for the A50 road link (Eindhoven-Oss, The Netherlands). Ecological Engineering, 7(4): 327-349

Cuperus R, Kalsbeek M, Haes H A U D, Canters K J (2002). Preparation and implementation of seven ecological compensation plans for Dutch highways. Environmental Management, 29(6): 736-749

Demetriades P O, Mamuneas T P (2000). Intertemporal output and employment effects of public infrastructure capital: evidence from 12 OECD economies. Economic Journal (London), 110(465): 687-712

Eisenhardt K M (1989). Building theories from case study research. Academy of Management Review, 14(4): 532-550

Fang Q, Elliott M (2016). China: prevent misuse of eco-compensation. Nature, 533(7603): 321-321

Ferraro P J, Hanauer M M (2014). Quantifying causal mechanisms to determine how protected areas affect poverty through changes in ecosystem services and infrastructure. Proceedings of the National Academy of Sciences of the United States of America, 111(11): $4332-4337$

Flyvbjerg B (2011). Over budget, over time, over and over again: managing major projects. In: Morris P W G, Pinto J, Jeffrey K, Söderlund J. The Oxford Handbook of Project Management. Oxford: Oxford University Press

Flyvbjerg B (2014). What you should know about megaprojects and why: an overview. Project Management Journal, 45(2): 6-19

Garriga E, Melé D (2004). Corporate social responsibility theories: mapping the territory. Journal of Business Ethics, 53(1): 51-71

Geels F W (2002). Technological transitions as evolutionary reconfiguration processes: a multi-level perspective and a case-study. Research Policy, 31(8-9): 1257-1274

Gibson J, Olivia S (2010). The effect of infrastructure access and quality on non-farm enterprises in rural Indonesia. World Development, 38 (5): 717-726

Godfrey P C (2005). The relationship between corporate philanthropy and shareholder wealth: a risk management perspective. Academy of Management Review, 30(4): 777-798

Haughwout A F (2002). Public infrastructure investments, productivity and welfare in fixed geographic areas. Journal of Public Economics, 83(3): 405-428

He Q H, Yang D L, Li Y K, Luo L (2015). Research on multidimensional connotations of megaproject construction organization citizenship behavior. Frontiers of Engineering Management, 2(2): 148-153 
Jones D A, Willness C R, Madey S (2014). Why are job seekers attracted by corporate social performance? Experimental and field tests of three signal-based mechanisms. Academy of Management Journal, 57(2): 383-404

Lin H, Zeng S, Ma H (2016). China: water scheme acts as ecological buffer. Nature, 529(7586): 283

Lin H, Zeng S X, Ge S L, Chen Y T (2017a). Can the bullet train speed up climate change mitigation in China? Frontiers of Engineering Management, 4(1): 104-105

Lin H, Zeng S X, Ma H, Zeng R, Tam V W (2017b). An indicator system for evaluating megaproject social responsibility. International Journal of Project Management, 35(7): 1415-1426

Lin X, Ho C M, Shen G Q (2017c). Who should take the responsibility? Stakeholders' power over social responsibility issues in construction projects. Journal of Cleaner Production, 154: 318-329

Liu J, Diamond J (2005). China's environment in a globalizing world. Nature, 435(7046): 1179-1186

Ma H, Zeng S, Lin H, Chen H, Shi J J (2017). The societal governance of megaproject social responsibility. International Journal of Project Management, 35(7): 1365-1377

Miller R, Hobbs J B (2005). Governance regimes for large complex projects. Project Management Journal, 36(3): 42-50

Mills A, Durepos G, Wiebe E, Pagano M P (2010). Encyclopedia of Case Study Research. Newbury Park, CA: Sage Publications

NOAA (1997). Natural resource damage assessment guidance document: scaling compensatory restoration actions (oil pollution act of 1990). Silver Springs, MD: US Department of Commerce, National Atmospheric and Oceanic Administration

O’Connor J E, Duda J J, Grant G E (2015). Ecology. 1000 dams down and counting. Science, 348(6234): 496-497

Pauget B, Wald A (2013). Relational competence in complex temporary organizations: the case of a French hospital construction project network. International Journal of Project Management, 31(2): 200211

Peng C, Ouyang H, Gao Q, Jiang Y, Zhang F, Li J, Yu Q (2007). Building a "green" railway in China. Science, 316(5824): 546-547

Qi G Y, Shen L Y, Zeng S X, Jorge O J (2010). The drivers for contractors' green innovation: an industry perspective. Journal of Cleaner Production, 18(14): 1358-1365

Qiu J (2007). Environment: riding on the roof of the world. Nature, 449 (7161): $398-402$

Shaw B, Post F R (1993). A moral basis for corporate philanthropy. Journal of Business Ethics, 12(10): 745-751

Shen L, Jiang S, Yuan H (2012). Critical indicators for assessing the contribution of infrastructure projects to coordinated urban-rural development in China. Habitat International, 36(2): 237-246

Stone R (2008). China's environmental challenges. Three Gorges Dam: into the unknown. Science, 321(5889): 628-632

Tam C M, Tam V W, Tsui W S (2004). Green construction assessment for environmental management in the construction industry of Hong Kong. International Journal of Project Management, 22(7): 563571

Trussart S, Messier D, Roquet V, Aki S (2002). Hydropower projects: a review of most effective mitigation measures. Energy Policy, 30(14): 1251-1259

Tseng M L, Lin Y H, Chiu A S (2009). Fuzzy AHP-based study of cleaner production implementation in Taiwan PWB manufacturer. Journal of Cleaner Production, 17(14): 1249-1256

Vidal L A, Marle F, Bocquet J C (2011). Measuring project complexity using the Analytic Hierarchy Process. International Journal of Project Management, 29(6): 718-727

Villarroya A, Puig J (2013). A proposal to improve ecological compensation practice in road and railway projects in Spain. Environmental Impact Assessment Review, 42: 87-94

Wang H, Qian C (2011). Corporate philanthropy and corporate financial performance: the roles of stakeholder response and political access. Academy of Management Journal, 54(6): 1159-1181

Westin J, Kågeson P (2012). Can high speed rail offset its embedded emissions? Transportation Research Part D, Transport and Environment, 17(1): 1-7

Wu J, Huang J, Han X, Xie Z, Gao X (2003). Ecology. Three-Gorges Dam-experiment in habitat fragmentation? Science, 300(5623): $1239-1240$

Xie P (2003). Three-Gorges Dam: risk to ancient fish. Science, 302 (5648): 1149-1151

Xu L, Yu B, Li Y (2015). Ecological compensation based on willingness to accept for conservation of drinking water sources. Frontiers of Environmental Science \& Engineering, 9(1): 58-65

Yin R K (2013). Case Study Research: Design and Methods. Newbury Park, CA: Sage publications

Yu B, Xu L (2016). Review of ecological compensation in hydropower development. Renewable \& Sustainable Energy Reviews, 55: 729738

Yu B, Xu L, Wang X (2016a). Ecological compensation for hydropower resettlement in a reservoir wetland based on welfare change in Tibet, China. Ecological Engineering, 96: 128-136

Yu B, Xu L, Yang Z (2016b). Ecological compensation for inundated habitats in hydropower developments based on carbon stock balance. Journal of Cleaner Production, 114: 334-342

Zeng S X, Ma H Y, Lin H, Zeng R C, Tam V W (2015). Social responsibility of major infrastructure projects in China. International Journal of Project Management, 33(3): 537-548

Zeng S X, Tam C M, Deng Z M, Tam V W (2003). ISO 14000 and the construction industry: survey in China. Journal of Management Engineering, 19(3): 107-115

Zhao Z Y, Zhao X J, Davidson K, Zuo J (2012). A corporate social responsibility indicator system for construction enterprises. Journal of Cleaner Production, 29-30: 277-289 